\title{
REGULAR ARTICLE \\ HERITABILITY ESTIMATES AND TRAITS ASSOCIATION IN WHEAT ADVANCED LINES
}

\author{
FAWAD ALI ${ }^{*}$, SHAHAB AHMAD ${ }^{2}$, JAVED ALI ${ }^{1}$, MEHRAN AYOOB TUNIO ${ }^{1}$, MUHAMMAD \\ SIDDIQUE AFRIDI ${ }^{1}$, TOUHEED IQBAL 3
}

${ }^{1}$ Department of Plant Sciences, Quaid-I-Azam University, Islamabad, Pakistan

${ }^{2}$ Department of Plant Breeding and Genetics, the University of Agriculture, Peshawar, Pakistan

3Agricultural Research Institute, Dera Ismail Khan, KP, Pakistan

\begin{abstract}
In the present investigation, 14 spring wheat advanced lines with four checks were evaluated for six yield parameters during 2011-12 in an RCB design with three replications. Results showed significant differences $(\mathrm{P} \leq 0.01)$ for all the studied traits except harvest index which showed significant differences ( $\mathrm{P} \leq 0.05)$. Mean values ranged between 87.7 to $110.4 \mathrm{~cm}$ for plant height, 29.1 to $38.1 \mathrm{~cm}$ for peduncle length, 1.91 to $2.89 \mathrm{~g}$ for grain weight spike-1, 5617.3 to $7197.5 \mathrm{~kg}$ for grain yield ha-1, 15679 to $20123 \mathrm{~kg}$ for biological yield ha $\mathrm{h}^{-1}$ and 34.94 to $42.40 \%$ for harvest index. Grain yield has significant correlation with grain weight spike $\mathrm{e}^{-1}\left(0.407^{* *}\right)$, biological yield $\left(0.486^{* *}\right)$ and harvest index $\left(0.549^{* *}\right)$. High heritability was observed for grain weight $\operatorname{spike}^{-1}(71.74 \%)$, grain yield ha-1 $(69.01 \%)$ and biological yield ha ${ }^{-1}(71.87 \%)$.
\end{abstract}

Keywords: Advanced lines, Heritability, Wheat

\section{INTRODUCTION}

Wheat (Triticum aestivum L.) is one among the major cereal crops of the world as a source of human diet and energy rich crop and also called as the "king of cereals". It occupies superior position in the international food grain [1]. Globally, Asia is the major sharer of the wheat production and produce more than $40 \%$ of the total wheat production (292.5 million tones) as compared to the world production (653.6 million tones). China is major wheat producing (115.5 million tones) country in Asia followed by India and Pakistan (80.8 and 23.3 million tones respectively). However, average yield per hectare of wheat in Pakistan is too low as compared to other countries [2]. In Pakistan, there is a production gap during last years. The production gap is due to a reduction in crop area, reduced availability of irrigation water, inputs (chemical fertilizers etc.) and low rainfall pattern. In Khyber Pakhtunkhwa wheat was grown on area of 0.725 million hectares with total production of 1.2 million tones. The yield in our province during 2010-11 was $1595 \mathrm{~kg} \mathrm{ha}^{-1}$ [3]. Wheat has always been subjected to extensive research work to maximize its production. Grain yield in cereals and particularly in wheat is a complex trait and is highly environment based and it results from interaction among its component sub-traits. Conducting wheat breeding programs, direct selection against yield is deceptive. Successful selections relay on genetic divergence, heritability estimates and association of agro-morphological traits with grain yield. The estimates of heritability along with correlation studies offer a better consideration of the association of important traits with grain yield [4].

Crop improvement depends on genetics during different breeding strategies. Higher the proportion of environmental variance less will be the chance to select inherited differences. Similarly, the rate of selection increases if the ratio of variability due to environmental factors is less than that of genetic variability [5]. It is therefore recommended to be sufficient knowledge about heritability and selection response for important yield related traits during crop improvement programs [6]. Traits having higher heritability could be selected during breeding programs which makes the progress easier to those traits containing low heritability estimates [7]. Numerous researchers reported high heritability estimates and selection response while studying different yield contributing traits during wheat improvement programs [8-10]. Grain yield is the most important polygenetic trait in cereal crops which is not only affected by external environment but also depends upon other yield related traits. Therefore, our selection should not be directly based upon grain yield but focus should also be given to other yield related traits. Besides the knowledge of

Received 11 November 2017; Accepted 29 December 2017

*Corresponding Author

Fawad Ali

Department of Plant Sciences, Quaid-I-Azam University, Islamabad

Email: fawadali365@gmail.com

(This article is open access and licensed under the terms of the Creative Commons Attribution License (http://creativecommons.org/licenses/by/4.o/) which permits unrestricted, use, distribution and reproduction in any medium, or format for any purpose, even commercially provided the work is properly cited. Attribution - You must give appropriate credit, provide a link to the license, and indicate if changes were made. 
heritability and selection response, the understanding of mutual relationship between different yield contributing traits is also noteworthy $[11,12]$. Present study was conducted to explore genetic variability, heritability and correlation among wheat advanced lines using six yield related traits to devise selection criteria for isolation of best performing lines in Peshawar valley.

\section{MATERIALS AND METHODS}

To assess the genetic variability and traits association in different wheat advanced lines, a field experiment was conducted during 2011-12 at the University of Agriculture, Peshawar. Breeding material used was 14 advanced lines along with 4 checks. The wheat genotypes were sown during mid of November 2011, with inter-row spacing of $30 \mathrm{~cm}$ in an RCB Design with three replications. Each subplot of a genotype had three rows. The recommended cultural practices such as land preparation, sowing and hoeing were similar for all treatments to minimize the environmental effects on breeding material.

\section{Statistical analysis}

The recorded data regarding each parameter were subjected to analysis of variance (ANOVA) techniques appropriate for RCB design through MSTATC software as outlined by Steel and Torrie [13] to compare the mean differences among wheat genotypes. Broad sense heritability was calculated for all parameters. Phenotypic correlation between these six traits was determined as suggested by following Kwon and Torrie [14].

\section{RESULTS AND DISCUSSIONS}

Results and discussions pertaining to six yield contributing traits are documented using heritability and traits association analysis.

\section{Analysis of variance}

Highly significant differences $(\mathrm{P} \leq 0.01)$ were observed for all the studied traits except harvest index which display significant differences ( $\mathrm{P} \leq 0.05)$ among wheat genotypes (table 1). Similar findings were reported by many researchers and confirmed our results [15, 16-23].

\section{Mean performance of the fourteen wheat advanced lines along with four checks}

Mean performance show us the actual genetic potential of different genotypes across different environments. We should identify and recommend genotypes performing better in an environment.

Table 1: Mean square values for plant height, peduncle length, grain weight spike-1, grain yield, biological yield and harvest index of wheat genotypes

\begin{tabular}{|c|c|c|c|c|}
\hline Source of variation & Replication & Genotype & Error & CV (\%) \\
\hline Degrees of Freedom & 2 & 17 & 34 & .......... \\
\hline Plant Height & 21.962 & $121.625^{* * *}$ & 16.271 & 4 \\
\hline Peduncle Length & 6.294 & $21.658^{* * *}$ & 1.824 & 3.92 \\
\hline Grain Weight Spike-1 & 0.157 & $0.201^{* *}$ & 0.07 & 11.6 \\
\hline Grain Yield & 227464.627 & $620356.163^{* *}$ & 242279.246 & 7.67 \\
\hline Biological Yield & 6858633.67 & $3953787.226^{* * *}$ & 1369037.849 & 6.9 \\
\hline Harvest Index & 12.487 & $18.498^{*}$ & 9.526 & 8.12 \\
\hline
\end{tabular}

**=Highly significant $(\mathrm{P}<0.01),{ }^{*}=$ Significant $(\mathrm{P}<0.05)$

Table 2: Mean performance for plant height, peduncle length, grain weight spike-1, grain yield, biological yield and harvest index of wheat genotypes

\begin{tabular}{|c|c|c|c|c|c|c|}
\hline Genotypes & $\begin{array}{l}\text { Plant height } \\
\text { (cm) }\end{array}$ & $\begin{array}{l}\text { Peduncle } \\
\text { length (cm) }\end{array}$ & $\begin{array}{l}\text { Grain weight } \\
\text { (g) }\end{array}$ & $\begin{array}{l}\text { Grain yield } \\
\left(\mathrm{Kg} \mathrm{ha}^{-1}\right)\end{array}$ & $\begin{array}{l}\text { Biological yield } \\
\left(\mathrm{Kg} \mathrm{ha}^{-1}\right)\end{array}$ & $\begin{array}{l}\text { Harvest } \\
\text { index (\%) }\end{array}$ \\
\hline MPT1 & 104.67 & 34.97 & 2.89 & 7098.76 & 16790.13 & 42.4 \\
\hline MPT2 & 92.73 & 32.46 & 2.38 & 6135.8 & 16419.77 & 37.46 \\
\hline MPT5 & 97.73 & 33.74 & 2.35 & 6703.7 & 17037 & 39.39 \\
\hline MPT6 & 95.87 & 34.52 & 1.99 & 6197.53 & 16790.13 & 36.86 \\
\hline MPT7 & 110.4 & 38.09 & 2.41 & 7197.53 & 20123.43 & 35.84 \\
\hline MPT8 & 108.67 & 37.27 & 2.45 & 6999.99 & 18641.97 & $37 \cdot 57$ \\
\hline MPT9 & 99.67 & 30.4 & 2.1 & 5888.88 & 16419.73 & 35.96 \\
\hline MPT10 & 102.93 & 35.91 & 2.07 & 6728.39 & 17901.23 & 37.58 \\
\hline MPT11 & 105.33 & $35 \cdot 55$ & 1.91 & 5617.28 & 16049.4 & 34.98 \\
\hline MPT12 & 108.07 & 36.88 & 2.28 & 6481.48 & 18148.13 & 36.05 \\
\hline MPT13 & 108.53 & 36.81 & 2.28 & 5888.89 & 16049.4 & 36.79 \\
\hline MPT14 & 102.73 & 34.46 & 2.02 & 6160.49 & 17037.03 & 36.21 \\
\hline MPT15 & 98.47 & 32.78 & 2.25 & 6851.85 & 16419.77 & 41.78 \\
\hline MPT16 & 97.13 & 36.44 & 1.95 & 6055.55 & 16419.77 & 37 \\
\hline ATTA HABIB & 94.6 & 32.84 & 2.5 & 6419.75 & 15802.5 & 40.6 \\
\hline SIREN & 95.47 & 30.13 & 2.32 & 6358.02 & 15679 & 40.68 \\
\hline $\begin{array}{l}\text { PIRSABAK- } \\
2005\end{array}$ & 87.67 & 29.09 & 2.14 & 6703.7 & 15925.93 & 42.07 \\
\hline $\begin{array}{l}\text { PIRSABAK- } \\
2008\end{array}$ & 105.33 & 37.42 & 2.69 & 6067.07 & 17530.9 & 34.94 \\
\hline MEAN & 100.89 & 34.43 & 2.28 & 6419.7 & 16954.73 & 38.01 \\
\hline LSD (0.05) & 6.69 & 2.24 & 0.44 & 816.75 & 1941.5 & 5.12 \\
\hline
\end{tabular}


Plant height ranged from 87.67 to $110.40 \mathrm{~cm}$ with a mean value of $100.89 \mathrm{~cm}$. Advanced line $\mathrm{MPT} 7 \mathrm{had}$ maximum plant height $(110.40 \mathrm{~cm})$, while Pirsabak-2005 had minimum plant height $(87.67 \mathrm{~cm})$. Peduncle length ranged from 29.09 to $38.09 \mathrm{~cm}$ with a mean value of $34.43 \mathrm{~cm}$. Maximum peduncle length was observed for MPT7 $(38.09 \mathrm{~cm})$, while minimum peduncle length was observed for Pirsabak-2005 $(29.09 \mathrm{~cm})$. Grain weight ranged from 1.91 to $2.89 \mathrm{~g}$ with an average of 2.28 g. Unlike, plant height and peduncle length, MPT1 showed maximum grain weight $(2.89 \mathrm{~g})$, while advanced line MPT11 had minimum grain weight $(1.91 \mathrm{~g})$. Grain yield ha ${ }^{-1}$ ranged from 5617.28 to $7197.53 \mathrm{~kg}$ with an average of 6419.70 $\mathrm{kg}$. Advanced line MPT7 exhibited maximum grain yield $(7197.53 \mathrm{~kg})$, while advanced line MPT11 showed minimum grain yield $(5617.28 \mathrm{~kg})$. Biological yield ha-1ranged from 15679.0 to $20123.4 \mathrm{~kg}$. Maximum biological yield ha-1 was observed for MPT7 (20123.4 kg), while minimum biological yield ha' ${ }^{-1}$ was observed for Siran $(15679.0 \mathrm{~kg})$. Harvest index ranged from 34.94 to $42.40 \%$. Advanced line MPT1 had maximum harvest index (42.40), while minimum harvest index was recorded for Pirsabak-2008 (34.94) (table 2).

Heritability estimation on entry mean base among six traits of the fourteen wheat advanced lines along with four checks

Heritability among fourteen advanced lines and four checks ranged from 61.66 to $92.03 \%$ for all the studied traits. Plant height revealed high heritability estimates (87.72\%) among fourteen advanced lines and four checks (table 3). In correspond to our study, earlier reports also observed higher magnitudes of heritability for plant height which support the present findings [24, 4]. Similarly, for plant height, high heritability estimates were also noticed by previous workers $[25,26]$.

Peduncle length revealed high heritability (92.03\%) among fourteen advanced lines and four checks (table 3). The results of Baranwal et al. [27] are in line with our findings who also exhibited similar heritability range for peduncle length. Grain Weight Spike $^{-1}$ exhibited high heritability (71.74\%) among fourteen advanced lines and four checks (table 3). These results are in conformation with the findings of Al-Tabbal and Al-Fraihat, [28]. For grains per spike, other researchers also reported high heritability estimates $[16,17]$. Grain yield ha-1 exhibited high heritability (69.01\%) among fourteen advanced lines and four checks (table 3). In correspond to our study, one of the previous studies also obtained high heritability for grain yield; however moderate heritability for the same trait was recorded [29]. Similarly, high heritability was also observed for grain yield [16]. Heritability estimate of $71.87 \%$ was obtained for biological yield (table 3 ). Our results are further supported by the previous findings who also reported similar heritability estimate for biological yield. Harvest index revealed heritability estimates of $61.66 \%$ (table 3 ). Similar effects were also found moderate heritability for harvest index [30].

\section{Pearson correlation analysis among six traits of the fourteen wheat advanced lines along with four checks}

Plant height was significantly correlated with peduncle length $\left(0.709^{* *}\right)$, biological yield $\left(0.423^{* *}\right)$ and harvest index $\left(0.270^{*}\right)$. Peduncle length was significantly correlated with biological yield $\left(0.434^{* *}\right)$ and harvest index $\left(0.405^{* *}\right)$. Grain weight spike ${ }^{-1}$ shown significant correlation with grain yield $\left(0.407^{* *}\right)$ and harvest index $\left(0.286^{*}\right)$. Grain yield was significantly correlated with biological yield (0.486**) and harvest index $\left(0.549^{* *}\right)$. Biological yield presented significant correlation with harvest index $\left(0.469^{* *}\right)$. Harvest index revealed significant correlation with all the studied traits like, plant height $\left(0.270^{*}\right)$, peduncle length $\left(0.405^{* *}\right)$, grain weight $\left(0.286^{*}\right)$ spike-1, grain yield $\left(0.549^{* *}\right)$, and biological yield $\left(0.469^{* *}\right)$ (table 4$)$.

Significant positive associations were obtained by Uddin et al. [31] between grain yield and grains spike ${ }^{-1}$, 1000-grain weight, flag leaf area and plant height. Further, many previous studies also found positive association between grain yield and grains spike ${ }^{-1}[32,17,12]$. Biological yield is positively associated with grain yield and suggests that grain yield increase parallel with biological as it assists to accumulate additional photosynthates in developing grain. This finding is supported by earlier works [33-35].

Table 3: Genotypic variance, phenotypic variance and heritability estimates for six yield contributing traits of wheat genotypes

\begin{tabular}{llll}
\hline Traits & Genotypic variance & Phenotypic variance & Heritability (\%) \\
\hline Plant Height & 38.73 & 44.16 & 87.72 \\
Peduncle Length & 7.02 & 7.62 & 92.03 \\
Grain Weight Spike-1 & 0.06 & 0.08 & 71.74 \\
Grain Yield & 179865.47 & 260625.22 & 69.01 \\
Biological Yield & 1165813.76 & 1622159.71 & 71.87 \\
Harvest Index & 5.11 & 8.28 & 61.66 \\
\hline
\end{tabular}

Table 4: Correlation coefficients for plant height, peduncle length, grain weight spike-1, grain yield, biological yield and harvest Index of wheat genotypes

\begin{tabular}{|c|c|c|c|c|c|c|}
\hline Traits & $\begin{array}{l}\text { Plant } \\
\text { height }\end{array}$ & $\begin{array}{l}\text { Peduncle } \\
\text { length }\end{array}$ & $\begin{array}{l}\text { Grain weight } \\
\text { spike-1 }^{-1}\end{array}$ & $\begin{array}{l}\text { Grain } \\
\text { yield }\end{array}$ & $\begin{array}{l}\text { Biological } \\
\text { yield }\end{array}$ & $\begin{array}{l}\text { Harvest } \\
\text { index }\end{array}$ \\
\hline Plant Height & ...... & $0.709^{* *}$ & $0.129 \mathrm{NS}$ & $0.132 \mathrm{NS}$ & $0.423^{* *}$ & $0.270^{*}$ \\
\hline Peduncle Length & $\ldots \ldots$ & ...... & $0.028 \mathrm{NS}$ & $0.015 \mathrm{NS}$ & $0.434^{* *}$ & $0.405^{* *}$ \\
\hline $\begin{array}{l}\text { Grain Weight } \\
\text { Spike }^{-1}\end{array}$ & $\cdots \cdots$ & $\cdots \cdots$ & $\cdots \cdots$ & $0.407^{* *}$ & $0.145 \mathrm{NS}$ & $0.286^{*}$ \\
\hline Grain Yield & ...... & $\ldots . .$. & $\ldots \ldots$. & $\ldots \ldots$ & $0.486^{* *}$ & $0.549 * *$ \\
\hline Biological Yield & ...... & ...... & $\ldots \ldots$ & $\ldots \ldots$ & $\ldots \ldots$ & $0.469^{* *}$ \\
\hline
\end{tabular}

${ }^{* *}=$ Highly significant $(\mathrm{P}<0.01),{ }^{*}=$ Significant $(\mathrm{P}<0.05), \mathrm{NS}=$ Non significant $(\mathrm{P}>0.05)$. 


\section{CONCLUSION}

It is concluded that genotypes MPT1, MPT7 and MPT15 showed superiority for various traits and hence the genetic potential of the mentioned wheat lines for the desired traits can be utilized in future wheat breeding programs. Also, the mentioned lines should be tested at various locations and be released as a variety.

\section{ACKNOWLEDGEMENT}

We are grateful to Department of Plant Breeding and Genetics, The University of Agriculture, PeshawarPakistan for the support by providing wheat seed and experimental area to carry out the research work.

\section{REFERENCES}

1. Tabinda, A and D. N. Bharwdaj. 2015. Study of Genetic Divergence in Wheat (Triticum aestivum L.). Agriculture Communications. 3(2): 1-6.

2. FAOSTAT. 2010. Food and Agriculture Organization of the United Nations.

3. FBS. 2011-12. Federal Bureau of Statistics, Islamabad.

4. Ali, Y., B. M. Atta, J. Akhtar, P. Monneveux and Z. Latif. 2008. Genetic variability, association and diversity studies in wheat (Triticum aestivum L.) Germplasm. Pakistan Journal of Botany. 40(5): 2087-2097.

5. Khan, M. A. 2001. Experimental design and analysis. Heritability estimation. 2, 210-211.

6. Haq, W., M. F. Malik, M. Rashid, M. Munir and Z. Akram. 2008. Evaluation and estimation of heritability and genetic advancement for yield related attributes in wheat lines. Pakistan Journal of Botany. 40(4): 1699-1702.

7. Shahid, M., F. Mohammad and M. Tahir. 2002. Path coefficient analysis in wheat. Sarhad Journal of Agriculture. 18(4): 383-388.

8. Arshad, M and M. A. Chowdhry. 2003. Genetic behavior of wheat under irrigated and drought stress environment. Asian Journal of Plant Sciences. 2(1): 58-64.

9. Khalil, I. H and N. Afridi. 2004. Heritabilities and selection responses for yield and yield associated traits in spring wheat. Sarhad Journal of Agriculture. 20(3): 401-404.

10. Inamullah., H. Ahmad, F. Mohammad, S. U. Din, G. Hassan and R. Gul. 2006. Evaluation of the heterotic and heterobeltiotic potential of wheat genotypes for improved yield. Pakistan Journal of Botany. 38(4): 1159-1167.

11. Akhtar, N and M. A. Chowdhary. 2006. Estimation of genetic and phenotypic correlation coefficients among grain yield and its components in bread wheat. International Journal of Agriculture and Biology. 8(4): 516-522.

12. Majumder, D. A. N., A. K. M. Shamsuddin, M. A. Kabirand and L. Hassan. 2008. Genetic variability correlated response and path analysis of yield and yield contributing traits of spring wheat. Journal of the Bangladesh Agricultural University. 6(2): 224227.

13. Steel, R. G. D and J. H. Torrie. 1980. Principles and procedures of statistics. McGraw-Hill Book Co, Inc., New York, USA.

14. Kwon, S and J. Torrie. 1964. Heritability and interrelationship among traits of two soybean populations. Crop Science. 4, 196-198.
15. Ahmad, I., N. Mahmood, I. Khaliq and N. Khan. 2016. Genetic analysis for five important morphological attributes in wheat (Triticum aestivum L.). Journal of Animal and Plant Sciences. 26(3): 725-730.

16. Kumar, A., A. Sirohi and S. Kumar. 2012. Studies of selection parameter in common bread wheat (Triticum aestivum L.). International Journal of Engineering and Science Research. 2(2): 90-94.

17. Baloch, M. J., G. M. Channa, W. A. Jatoi, A. W. Baloch, I. H. Rind, M. A. Arain and A. A. Keerio. 2016. Genetic characterization in $5 \times 5$ diallel crosses for yield traits in bread wheat. Sarhad Journal of Agriculture. 32(3): 127-133. https://doi. org/10.17582/journal. sja/2016/32.3.127.133

18. Beche, E., C. L. Silva, E. S. Pagliosa, M. A. Capelin, J. Franke, G. Matei and G. Benin. 2013. Hybrid performance and heterosis in early segregant populations of Brazilian spring wheat. Australian Journal of Crop Science. 7(1): 51-57.

19. Masood, M. S., A. Javid and M. A. Rabbani. 2005. Phenotypic diversity and trait association in bread wheat (Triticum aestivum L.) landraces from Baluchistan, Pakistan. Pakistan Journal of Botany. 37(4): 949-957.

20. Gashaw, A., H. Mohammed and H. Singh. 2010. Genotypic Variability, Heritability, Genetic Advance and Associations among Characters in Ethiopian Durum Wheat (Triticum durum Desf.) Accessions. East African Journal of Sciences. 4(1): 27-33.

21. Thanna, H. A., A. E. Kareem and A. E. Saidy. 2011. Evaluation of yield and Grain quality of some bread Wheat genotypes under normal irrigation and drought stress condition in calcareous soil. Journal of BioScience. 11(2): 156-164.

22. Empilli, S., R. Castagna and A. Brandolini. 2000. Morpho-agronomic variability of the diploid wheat Triticum monococcum L. Plant Genetic Resources Newsletter No. 124, 36-40.

23. Butnaru, G., I. Sarc, A. Blindar, L. Holly and I. Mar. 2003. Morphoagronomic variability of Triticum monococcum L. land races in the Timisoara area. Hunedoara. Romania; ISIRR, Section IV: 167-172.

24. Ajmal, S. U., N. Zakiri and M. Y. Mujahid. 2009. Estimation of genetic parameters and character association in wheat. Journal of Agricultural and Biological Science. 1(1): 15-18.

25. Farshadfar, E., F. Rafiee and H. Hasheminasab. 2013. Evaluation of genetic parameters of agronomic and morpho-physiological indicators of drought tolerance in bread wheat (Triticum aestivum L.) using diallel mating design. Australian Journal of Crop Science. 7(2): 268275 .

26. Kumar, D and S. A. Kerkhi. 2015. Genetic variability, heritability and genetic advance for yield component and quality traits in spring wheat (Triticum aestivum L.). Bioscan. 10(4): 2125-2129.

27. Baranwal, D. K., V. K. Mishra, M. K. Vishwakarma, P. S. Yadav and B. Arun. 2012. Studies on genetic variability, correlation and path analysis for yield and yield contributing traits in wheat (Triticum aestivum L. Em Thell). Plant Archives. 12(1): 99-104.

28. Al-Tabbal, J. A and A. H. Al-Fraihat. 2012. Heritability studies of yield and yield associated traits in wheat genotypes. Journal of Agricultural Science. 4(4): 11-22.

29. Khan, I., I. H. Khalil and Nasir-ud-Din. 2007. Genetic parameters for yield traits in wheat under irrigated and 
rainfed environments. Sarhad Journal of Agriculture. 23(4): 973-980.

30. Khalid, M., I. H. Khalil, Farhatullah, A. Bari, M. Tahir, S. Ali, S. Anwar, A. Ali and M. Ismail. 2011. Assessment of heritability estimates for some yield traits in winter wheat (Triticum aestivum L.). Pakistan Journal of Botany. 43(6): 2733-2736.

31. Uddin, F., F. Mohammad and S. Ahmed. 2015. Genetic divergence in wheat recombinant inbred lines for yield and yield Components. Academia Journal of Agricultural Research. 3(10): 303-307.

32. Anwar, J., M. A. Ali, M. Hussain, W. Sabir, M. A. Khan, M. Zulkiffal and M. Abdullah. 2008. Assessment of yield criteria in bread wheat through correlation and path analysis. Journal of Animal and Plant Sciences. 19(4): 185-188.
33. Bahari, N., B. B. Bighdilu and L. Karpisheh. 2014. Studying the correlation and analyzing the path coefficient between grain weight and the traits related to remobilization of assimilates in bread wheat genotypes. Journal of Biodiversity and Environmental Sciences. 4(3): 303-308.

34. Chaturvedi, B. K and R. R. Gupta. 1995. Selection parameters for some grain and quality attributes in spring wheat (T. aestivum L.). Agricultural Science Digest. 15(4): 186-190.

35. Subhani, G. M., S. Ahmed and M. A. Chowdhury. 2000. Correlation and path coefficient analysis in bread wheat under drought stress and normal conditions. Pakistan Journal of Biological Sciences. 3(1): 72-77. 